\title{
Microwave-assisted Extraction of Natural Dyes from Coleus atropurpureus Leaves: The Effect of Solvent
}

\author{
Selfina Gala, Sumarno Sumarno, and Mahfud Mahfud* \\ Department of Chemical Engineering, Institut Teknologi Sepuluh Nopember, Surabaya, Indonesia \\ *Corresponding authors: mahfud@chem-eng.its.ac.id (M. Mahfud); selfinagala90@gmail.com (S. Gala)
}

\begin{abstract}
A microwave-assisted extraction system was used to extract natural dyes from Coleus atropurpureus leaves. The effects of water solvent of the temperature at $100^{\circ} \mathrm{C}$ and $80^{\circ} \mathrm{C}$ as well as ethanol solvent $96 \%$ were investigated. This is done at the various material to solvent ratio $(0.001,0.0025,0.005 \mathrm{~g} / \mathrm{mL})$ and microwave power $(264,400,600$ watt). The optimal conditions of the extraction were obtained on a water solvent of the temperature at $100^{\circ} \mathrm{C}$ with material to solvent ratio $0.001 \mathrm{~g} / \mathrm{mL}$, irradiation power 400 watt, extraction time $10 \mathrm{~min}$, material size 35-60 mesh, the optimum yield of $44.48 \%$. Identification of groups of pigments contained in the Coleus atropurpureus leaves is known categories tannins and flavonoids. Fourier Transform Infrared Spectroscopy was used to identify the major chemical groups in the extracted dyes.
\end{abstract}

Keywords: Coleus atropurpureus, extraction, natural dye, microwave, solvent

\section{Introduction}

The dye is an organic compound of natural or synthetic sources which are used to give color to the object. Natural dye (pigment) is a dye that is naturally present in plants, animals and minerals. Until now, the main source of natural dyes derived from plants [1-2]. The dye used in the textiles, food, beverages, pharmaceuticals, cosmetics, ink printers, home appliances and others. The use of dyestuffs is inevitable in the interests of the industry because color has a meaning and a very important role where the color is the appeal of a product also as a quality attribute, especially on textile products.

Currently, the needs of textile products increased thereby increasing the use of synthetic dyes in the textile industry. Synthetic dye is widely used because it is more easily obtained and practical use and the resulting color is more diverse. In addition the use of a small amount is sufficient to provide the desired color. But the use of synthetic dyes pose a new problem that environmental pollution. Disposal of synthetic dye waste without first processing will pollute the environment, especially the surrounding aquatic environment.

Natural dyes become widespread with the increasing awareness of the negative impact of synthetic dyes on the environment and the wearer. Advantages of natural dyes are non-toxic, non-carcinogenic, renewable resources, environmentally friendly, reducing pollution and no allergic reaction on the skin. Some natural sources produce really beautiful dyes for textile applications and economical price compared to synthetic dyes [3-5]. In addition, the plant-based natural dyestuffs also function as antibacterial, antioxidant and anticarcinogenic due to the presence of a pigmental group containing phenolic components [6-10].

One of the plants that can be explored for natural dyes is Coleus atropurpureus. This plant is widely grown in the tropics, especially in Asia including Indonesia and has a variety of colors on the leaves (red, yellow, pink, green and maroon). The name of these plants vary widely and have different names with different subspecies such as $C$. blumei, $C$. atropurpureus, C. scutellarioides, C. bicolor, $C$. versschaffelti and $C$. hybridus. However, in some publications use the name $C$. blumei [11]. The pigment content present in this coleus leaf is tannin [11-12], flavonoid and tannin [13].

At first all natural coloring materials obtained by traditional extraction method is by boiling raw materials and water as a solvent. For laboratory scale is usually done by conventional methods such as reflux and soxletation. This method requires a long time, the relatively large amount of solvent to extract low yield [5], [14-18]. It is encouraging technology innovation extraction process performed by using microwaves as an

Corresponding author: mahfud@chem-eng.its.ac.id; selfinagala90@gmail.com 
energy source with optimal results in a relatively short time. This method also includes "green techniques" for natural dye extraction process.

In this study, the solvents used are water and ethanol that are environmentally safe, cheap and have relatively large dieletric constants. Therefore, this study aims to determine the effect of solvent on the results of microwave-assisted extraction.

\section{Materials and Metods}

\subsection{Materials and chemicals}

The material used in this research, Coleus atropurpureus leaves was obtained from South Sulawesi, Indonesia. The powdered Coleus atropurpureus leaf were passed through $>35$ mesh filter. Analytical grade of ethanol $(96 \% \mathrm{v} / \mathrm{v})$ and distilled water as a solvent.

Hydrochloric acid, ferric chloride, sodium chloride and $\mathrm{Mg}$ powders is used for phytochemical test. All chemicals used were obtained from domestic distributors in Indonesia.

\subsection{Microwave-assisted extraction (MAE)}

The tool used a domestic microwave oven Electrolux model EMM2007X with $2450 \mathrm{MHz}$ Magnetron frequency, maximum delivered power of $800 \mathrm{~W}, 220 \mathrm{~V}$ voltage. Oven dimension with length $46.1 \mathrm{~cm}$, width $28.0 \mathrm{~cm}$ and height $37.3 \mathrm{~cm}$. The extraction process is carried out in a three round neck flask extractor equipped with a condenser placed at the top of the oven. The temperature inside the extractor flask was measured with $\mathrm{K} 1 / 16$ inc thermocoppel type fitted to a microwave oven.

Raw materials was milled, sifted to a certain size (35-60 mesh). Powder and solvent was fed into extractor. Water flowed on the cooling system (condensor). After the extraction process in the oven is complete, the extract then filtered with filter paper (whatman no.1, $90 \mathrm{~mm}$ diameter) using a vacuum filter.The obtained extract solution was concentrated and dried at a temperature of $60-80^{\circ} \mathrm{C}$ to a constant weight.

\subsection{Determination of extraction yield of Coleus atropurpureus leaves (CAL)}

The yield of Sample produced from MAE, extractions were calculated by:

$$
\mathrm{y}=\frac{s}{W} \times 100
$$

where $\mathrm{y}$ is extraction yield $(\%, \mathrm{w} / \mathrm{w}), \mathrm{S}$ is mass of extracted yield (g), and $\mathrm{W}$ is mass of Coleus atropurpureus leaves (g).

\section{Results and discussion}

One important factor that affects the extraction results with a microwave is the choice of solvent. Selection of suitable solvents can make the extraction process work more efficiently. In general, the capacity of the solvent to absorb the microwave energy will be high when the solvent used has a high dielectric constant values [19]. The value of the dielectric constant indicates the ability of the solvent to be polarized by an external electric field and can be regarded as a relative measure of microwave energy density [20]. The dielectric constant also plays an important role in determining the interaction between the electric field to the matrix, so the higher the dielectric constant value that is owned by the solvent, the solvent will be getting better at absorbing microwave energy.

\subsection{Effect of solvent on extraction}

In this study used ethanol and distilled water as solvent. Water solvent is an environmentally friendly solvent because it is not toxic, non-mutagenic, and is not carcinogenic [21]. While the ethanol solvent selection is based on its polarity and has a high dielectric constant value of about 24.3 [22], which is quite good in microwave absorption. Ethanol is the safest alcohol used because it has at least toxic properties that can be used for the consumer product industry [23]. Also important is that because at atmospheric conditions the boiling point of ethanol is $78^{\circ} \mathrm{C}$ and does not degrade the pigment (natural dye).

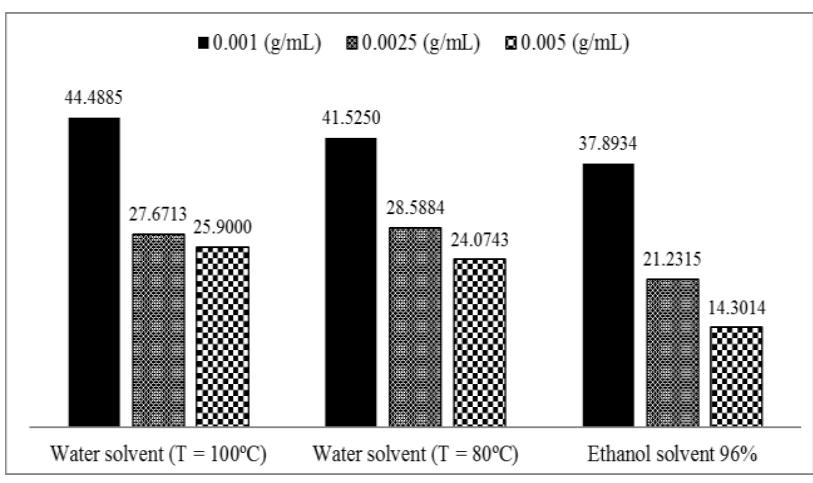

Fig 1. Effect of solvent type on the yield of CAL extraction on various material to solvent ratio (microwave power of 400 watt, time of $10 \mathrm{~min}$, material size of $>35 \mathrm{mesh}$ )

Figure 1 shows the best condition for the use of water solvent with temperature in extractor controlled $100^{\circ} \mathrm{C}$, material to solvent ratio at $0.001 \mathrm{~g} / \mathrm{mL}$ with an optimum yield of $44.4885 \%$. This can happen because the water has polarity properties and high dielectric constant is approximately 80.4 [22], so it is very good in microwave absorption. In addition, it is also possible because the leaves contain lot of bioactive including pigment dyes that are more soluble in water than ethanol.

Figure 1 also shows that the ratio of the material to the smaller solvent in the extraction system can cause the solvent to be more in contact with the material. This leads to more dye that can be extracted. If the use of the 
volume of solvent that more will cause cell swelling or materials so that the pressure pushes the cell wall, stretch and facilitate the breakdown of cell walls and the release of the dye into the solvent [24-25].

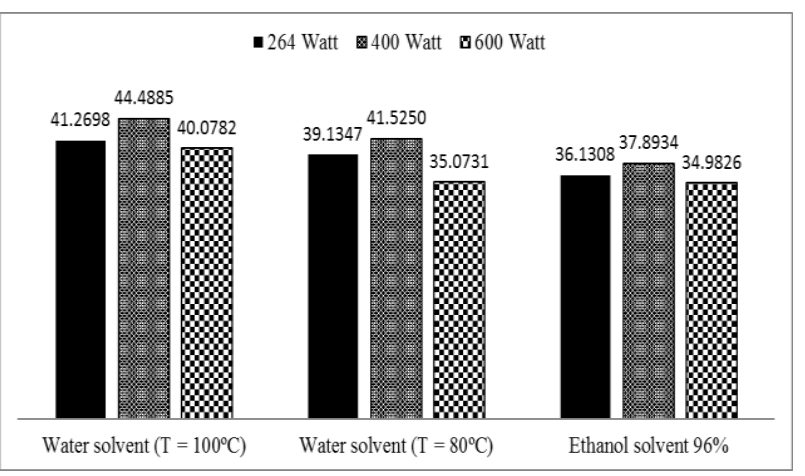

Fig 2. Effect of solvent type on the yield of CAL extraction on various microwave power (material to solvent ratio of 0.001 $\mathrm{g} / \mathrm{mL}$, time of $10 \mathrm{~min}$, material size of $>35 \mathrm{mesh}$ )

Figure 2 shows that the power of 600 watt was obtained a smaller yield than to power $264 \mathrm{~W}$ and 400 $\mathrm{W}$. This is due to the greater the power of microwave used then the system temperature of the extraction process will be more rapid increase and reached the boiling point of the solvent used. Achievement of the boiling point in faster time results in faster solvent evaporation resulting in reduced solvent volume to penetrate into the material.

\subsection{Qualitative analysis extracted dyes}

This research is conducted qualitative test pigment component which is found in extracts by phytochemical test (pigment identification) and Fourier Transform Infrared Spectrometry (the identification functional groups of extracted dye).

\subsubsection{Phytochemical test}

Phytochemical test performed on extracts produced by the method of cold maceration (extraction without the provision of heat) and the MAE (The temperature in the extractor around $100^{\circ} \mathrm{C}$ ). The result of phytochemical test identified that flavonoids, tannins, and quinones are found in Coleus atropurpureus leaves. This can be shown in table 1.

Table 1. Pigment identification of Coleus atropurpureus leaves

\begin{tabular}{|c|c|c|c|c|c|}
\hline \multirow{2}{*}{$\begin{array}{c}\text { Types } \\
\text { of material }\end{array}$} & \multirow{2}{*}{$\begin{array}{c}\text { Types } \\
\text { of pigment }\end{array}$} & \multirow[t]{2}{*}{ Reagents } & \multirow[t]{2}{*}{ Observation } & \multicolumn{2}{|c|}{ Test results } \\
\hline & & & & $\begin{array}{l}\text { Maceration } \\
\text { (2 days) }\end{array}$ & \begin{tabular}{|c|} 
MAE \\
$(10 \mathrm{~min})$
\end{tabular} \\
\hline \multirow{3}{*}{$\begin{array}{c}\begin{array}{c}\text { Coleus } \\
\text { atropurpureus }\end{array} \\
\text { leaves }\end{array}$} & Flavonoid & $\begin{array}{c}\text { Mg powder }+ \\
\mathrm{HCl}\end{array}$ & Yellow & + & ++ \\
\hline & Tannin & $\mathrm{NaCl}+\mathrm{FeCl}_{3}$ & $\begin{array}{c}\text { Blackish } \\
\text { green }\end{array}$ & + & + \\
\hline & Quinone & $\mathrm{NaOH}$ & $\begin{array}{c}\text { Yellowish } \\
\text { green }\end{array}$ & - & - \\
\hline
\end{tabular}

\subsubsection{Characterization of the extracted dye with FTIR Spectrometer (Fourier Transform Infra Red)}

Qualitative analysis of functional groups on the raw material and extract the dye after extraction with MAE is done by interpreting the absorption peaks of the infrared spectrum. In Figure 3. shows the FTIR spectra of raw materials and extract, where the results of these spectra are used to observe changes in the structure or functional group of substances after extraction with microwave.

The results show a ribbon stretching extract (vibration strain) $-\mathrm{OH}$, but the $-\mathrm{OH}$ group on raw materials (Figure 3a) indicate the presence of free $-\mathrm{OH}$ groups (provide absorption with greater frequency with sharp intensity). While in Figure 3b shows the formation of group - $\mathrm{OH}$ bound (the hydrogen bonds) are on the uptake with lower frequency and width and a shift in the absorption band.

(a)

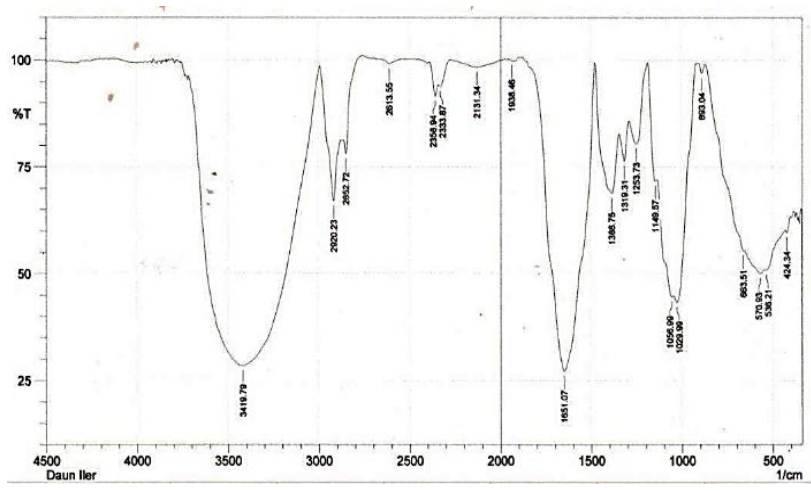

(b)

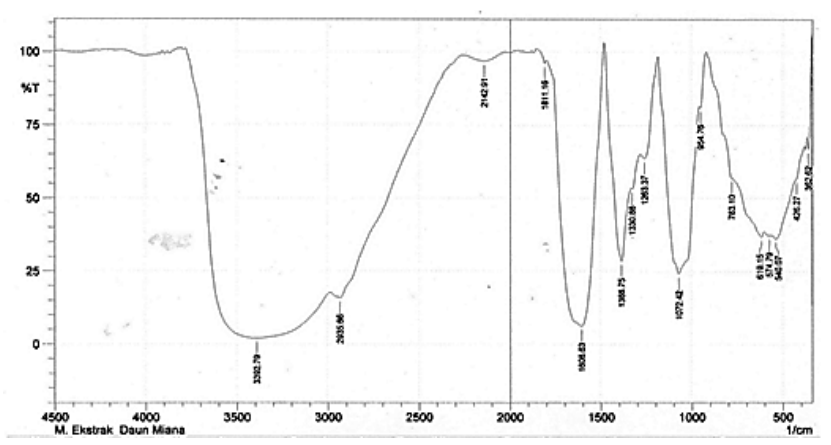

Fig 3. FTIR spectra of Coleus atropurpureus leaves: (a) before the extraction, (b) After the extraction with MAE (microwave power of 400 watt, extraction time for $10 \mathrm{~min}$ ) 
The FTIR spectra analysis of the extracted dye after the extraction with MAE show distinct peaks at 3392, 2935, 2142, 1811, 1606, $1330-1388,1263,1072,954$ $\mathrm{cm}^{-1}$ respectively (Fig 3 ). The broad and strong band at $3392 \mathrm{~cm}^{-1}$ can be attributed to bonded $-\mathrm{OH}$ groups. The peak at $2935 \mathrm{~cm}^{-1}$ is indicative of $\mathrm{C}-\mathrm{H}$ stretching vibration, $-\mathrm{C} \equiv \mathrm{N}$ stretching of $2142 \mathrm{~cm}^{-1}, \mathrm{C}=\mathrm{O}$ stretching of $1811 \mathrm{~cm}^{-1}, \mathrm{C}=\mathrm{C}$ stretching of $1608 \mathrm{~cm}^{-1}, \mathrm{C}-$ $\mathrm{H}$ bending of $1330-1388 \mathrm{~cm}^{-1}, \mathrm{O}-\mathrm{H}$ bending of $1263 \mathrm{~cm}^{-}$ ${ }^{1}, \mathrm{C}-\mathrm{O}$ stretching of $1072 \mathrm{~cm}^{-1}, \mathrm{C}-\mathrm{C}$ stretching of 954 $\mathrm{cm}^{-1}$.

In FTIR spectrometry analysis, it is identified that there is a functional groups of the chromophore such as carbonyl groups $(\mathrm{C}=\mathrm{O})$ and ethylene groups $(\mathrm{C}=\mathrm{C})$. Functional groups of auxochrome, hydroxyl groups ($\mathrm{OH}$ [27].

\section{Conclusion}

Extraction of natural dyes from Coleus atropurpureus leaves have been successfully performed using MAE. The optimum condition is obtained on the use of water solvent with temperature control of $100^{\circ} \mathrm{C}$, material to solvent ratio of $0.001 \mathrm{~g} / \mathrm{mL}$, microwave power of 400 watt with extraction yield of $44.49 \%$. The identification of pigments with phytochemical test shows the presence of pigment tannin and flavonoid on the extract dyes. In FTIR spectrometry test, it is identified that there is a functional group of the chromophore such as carbonyl groups $(\mathrm{C}=\mathrm{O})$ and ethylene group $(\mathrm{C}=\mathrm{C})$. Group of auxochrome, hydroxyl (-OH).

\section{Acknowledgement}

This work was financially supported by Ministry of Technology Research and Higher Education of Indonesia (1523/K9/KT.03/2017).

\section{References}

1. H. Goodarzian, E. Ekrami, World Appl Sci J, 8, 11 (2010)

2. L.G. Angelini, I. Pistelli, P. Belloni, A. Bertoli, S. Panconesi, Rubia Tinctorum a source of natural dyes: Agronomic evaluation, Ind. Crops Prod., 6 (1997)

3. S. Ali, T. Hussain, R. Nawaz, J. Cleaner Prod., 17, 1 (2009).

4. P. Leitner, C. Fitz-Binder, A. Mahmud-Ali, T. Bechtold, Dyes Pigm., 93, 1-3 (2012)

5. K. Sinha, P.D. Saha, S. Datta, Ind. Crops Prod., 37, $1,(2012)$

6. R.M. Selvam, G. Athinarayanan, A.U.R. Nanthini, A.J.A. Ranjit Singh, K. Kalirajan, P.M. Selvakumar, Ind. Crops Prod., 70 (2015).

7. M.P. Sathianarayanan, N. Bhat, S.S. Kokate, V.E. Walunj, Antibacterial finish for cotton fabric from herbal product (India Fiber Text Res, 2010).

8. F. Anwar, M. Ali, A.I. Hussain, M. Shahid, Flavour Fragrance J., 24, 4 (2009)
9. A.P. Kulkarni and S.M. Aradhya, Food Chem. 93, 2 (2005)

10. M. Riaz, N. Rasool, I.H. Bukhari, K. Rizwan, F. Javed, A.A. Altaf, H.M.A. Qayyum, Oxid. Commun. 36, 1 (2013)

11. A. Nagpal, B. Singh, S. Sharma, G. Rani, V.G. Singh, Medicinal and Aromatic Plant Science and Biotechnology, (Global Science Books, 2008)

12. D. Rizal and W.D.R. Putri, Journal of Food and Agro-Industry, 2, 4 (2014)

13. Y. Ridwan and Y.Q. Ayunita, Journal of Protein, 14, 1 (2007)

14. M.F.B. Vazquez, I.R. Comini, R.E. Martini, M.S.C. Nunez, S. Bottini, J.L.Cabrera, Ultrason. Sonochem. 21,2 (2014)

15. S. Umale and P.A. Mahanwar, Int. J. Basic Appl. Sci. 12, 1 (2012)

16. W. Xiao, L. Han, B. Shi, Sep. Purif. Technol. 62 (2008)

17. K. Sinha, S. Chowdhury, P.D. Saha, S. Datta, Ind. Crops Prod., 41(2013)

18. I.V. Karabegovic, S.S. Stojicevic, D.T. Velickovic, N.C. Nokolic, M.L. Lazic, World Academy of Science, Engineering and Technology, International Journal of Biological, Biomolecular, Agricultural, Food and Biotechnological Engineering. 6, 11 (2012)

19 G. Spigno, and D.M. De Faveri, J. Food Eng., 93 (2009)

20 G.G. Raju, Dielectrics in Electric Fields (Dekker, New York, 2003)

21 Material safety data sheet, Water MSDS,(2005).

22 A.C. Metaxas, Foundations of Electroheat: A unified Approach (Wiley, New York, 1996)

23. Material safety data sheet, Ethyl Alcohol, (2001)

24 I. Calinescu, C. Ciuculescu, M. Popescu, S. Bajenaru, G. Epure, RICCCE, 12, (2001)

25 J.P. Maran, V. Sivakumar, K. Thirugnanasambandham, R. Sridhar, Carbohydr. Polym., 97, 2, (2013)

26 U. Supratman, Structure elucidation of organic compounds: spectroscopic methods for structure determination of organic compounds, (Publisher Widya Padjadjaran, Bandung, 2010) 